\title{
Military Expenditures and Economic Growth in Pakistan
}

\author{
NASIR M. KHILJI and AKHTAR MAHMOOD
}

\begin{abstract}
This paper explores the impacts of defence expenditures on economic growth and other major economic variables in the Pakistan economy over the period 1972-1995. The results of Granger-causality tests show that there is bi-directional feedback between the defence burden and GDP growth. We test four different single equation models that are widely used in the defence literature. In these frameworks we generally find the defence burden to be negatively related to GDP growth. Finally, we specify a three-equation model which explains GDP growth, average propensity to save, and the defence ratio. In single equation estimations of the savings ratio and the defence burden, we uncover some interesting relationships. The savings ratio is affected positively by the defence ratio, and negatively by the inflation rate. The Pakistani defence burden is impacted negatively by the Indian defence burden and positively by the government budget. When all three equations are estimated as a system to account for feedback and covariance between these equations, these effects are diminished and go down in statistical significance.
\end{abstract}

\section{INTRODUCTION}

One of the first things taught to students of economics is that no economy has unlimited primary resources. There are a maximum of types of goods and services that can be produced with these resources at a point in time. In order to produce more of a particular type of good or service, in a fully employed economy, other goods have to be sacrificed. The production possibilities frontier is normally used to illustrate this concept and one of the classic examples provided is the bread versus guns choice. The point being that if a society chooses to allocate more resources to defence, it will have to make do with less consumer products. Moreover, since defence takes away resources that partly could have been devoted to producing

Nasir M. Khilji is with the U.S. Bureau of the Census. He is Economic Adviser to the U.S./Saudi Arabian Joint Commission for Economic Cooperation, Riyadh, Saudi Arabia and Akhtar Mahmood is a former Secretary, Government of Pakistan.

Authors' Note: We had fruitful discussions with and received helpful comments from Faizullah Khilji. We are grateful to Rehana Siddiqui, the official discussant in the 13th PSDE Conference, for her thorough review of the paper and her useful comments and suggestions. We also appreciate comments received from the floor. The findings, interpretations, and conclusions are only those of the authors and should not be attributed to any of the institutions with which they are or have been affiliated. The responsibility for any errors rests with the authors. 
investment goods, the economy's growth potential is retarded as a consequence of increased defence allocation. While this argument holds at a point in time, it may not be the case over time. It may be the case that resources devoted to defence at one point in time have positive effects on other sectors of the economy both in the present and in the future so that the ability of the economy to produce more of all goods in the future is enhanced.

For the developed countries, it has been shown that increased defence spending is inversely related to rates of economic growth, investment, and employment. [Smith (1977); Boretsky (1975) and Sivard (1977).] For the developing countries the evidence is less clear cut. What is the effect of military expenditures on the development process? There have been numerous attempts to answer this question since the seminal work of the late Emile Benoit (1973) that found a positive correlation between defence spending and GDP growth in a cross-section of 44 countries. ${ }^{1}$ Before we review some of the subsequent work, it would be useful to lay out the ways (not necessarily mutually exclusive) that defence spending is purported to affect development and economic growth.

The first way is the Keynesian notion of the creation of additional aggregate demand. As, Benoit (1973); Faini et al. (1984) and others have suggested, if aggregate demand is initially inadequate relative to potential supply, the increase in aggregate demand of higher defence spending, through multiplier effects, may lead to increased utilisation of the capital stock and greater employment of labour. An efficient capacity utilisation may lead to an increase in the profit rate, which will stimulate investment and ultimately increase the growth rate. While this argument may hold for economies characterised by deficient aggregate demand, it is doubtful that it applies to developing economies characterised by supply constraints.

The second major way that defence can affect growth is the standard textbook idea of opportunity costs alluded to above. Military expenditures divert resources away from other uses and may have a direct opportunity cost in terms of foregone investment. By reducing potential savings available for planned investment, it enlarges the savings-investment gap. If a substantial part of armaments is imported, as in Pakistan, then this also imposes a balance-of-payment problem on the economy. Critics of this view argue that resources are not diverted from investment but rather socially wasteful expenditures [Benoit (1973)]. Regarding the balance-ofpayment problem it is countered that military and economic security are complements, and that if donors consider military and economic aid to be correlated, one may lead to the other, such as Pakistan in the early 1960s and during the Afghanistan war. Therefore foreign aid may pay for part of defence, especially imported armaments.

The third way is the idea that there are several spin-offs that are a consequence of military expenditures and can be beneficial to growth, though not

${ }^{1}$ Ball (1983) has an extensive critique of this work. 
always so. On the one hand, the military may engage in R \& D, provide technical skills, organise rural labour (as soldiers) to accept discipline, give educational training and medical care, introduce new technology, and/or create infrastructure. On the other hand, the appropriateness and adequacy of such technology, infrastructure, ethos, and discipline are subject to question, since it is possible, that security-related objectives may not be beneficial to civilian needs.

Finally, military expenditures may influence growth through the creation and mobilisation of new resources. One way in which this can happen is through inflation. In aggregate-supply-constrained economies defence spending is inflationary. Inflation may lead to "forced saving," an increased supply of new resources lured by high prices, or a rise in profitability that induces higher investment. However, it is also possible that expectations of continuing inflation might cause an increase in consumption expenditures, and investment in sectors that have little growth potential.

There exists a substantial body of research, composed of empirical studies, attempting to quantify these various influences of military expenditures on developing countries' growth rates. Three strands of this literature can be discerned. Following Benoit, the first line of research has been concerned primarily with analysing the relationship between defence and economic growth. Most of this work relies on crosssection data for as large a number of countries as are possible. Averages of the relevant variables over a decade or two for each country are computed. Some studies have supported Benoit's findings while others have found a statistically significant negative impact of defence spending on economic growth. After an extensive review of these studies, Chan (1985) concludes, on page 433, that '... there is no consensus about the actual existence and nature of such an impact.' He goes on to say that '....we have probably reached a point of diminishing returns in relying on aggregate cross-national studies to inform us about the economic of defence spending.... Future research will profit more from discriminating diachronic studies of individual countries'.

The second line investigates causality between defence spending and economic growth. While not much work was done in this area in the seventies, it is being rapidly populated by empirical studies as longer time series on individual countries become available. The third, and more recent, line of research introduces political instability into the analysis and focuses on its relationship to defence or to economic growth. For example, Hess and Orphanides (1991) develop a model to analyse the relationship between defence and political instability. They provide the conditions necessary for an elected official to start an unnecessary war to increase his or her probability of re-election. Others, such as Alesina et al. (1991) and Londregan and Poole (1990), have investigated the empirical relationship between political instability and growth. Grossman (1991) links political events to economic activities. $^{2}$

${ }^{2}$ See Blomberg (1996) for more on this literature. 
This paper is related mainly to the first two areas of research. The third area where political stability is linked to defence and growth requires the computation of an index of political stability/instability and other hard to quantify variables. Computing indices for political variables would be a major research effort by itself. This paper attempts to fill a gap in the empirical literature on the economics of defence and growth by focussing on a single country. As noted previously such case studies are rare.

As far as we know, not much work has been done on examining the relationship between defence spending, economic growth, and other major economic variables for Pakistan. Baffes and Shah (1993) employ a flexible production structure methodology, where public and private inputs interact and contribute to national output. Public capital is disaggregated into infrastructure, human resource development and military capital stocks. Based on an analysis of time-series (196584 ) and cross-section (25 countries including Pakistan), the paper concludes that the contribution of military spending to economic growth appears to be negative for a substantial number of countries. Pakistan is among them and its output elasticity with respect to military capital is found to be -0.02 . Bayoumi et al. (1993) investigate the economic impact of a co-ordinated reduction in military expenditures of 20 percent using a specially modified version of the MULTIMOD world economic model. Simulation results for Pakistan indicate that the size in the cuts in military spending allow for a relatively large increase in private consumption and investment in both the short- and long-run. Economic welfare increases by 113 percent of 1992 GDP, compared with military spending cuts equivalent to 93 percent of 1992 GDP.

Both the studies mentioned for Pakistan use pooled data sets covering a large number of countries and allow for some fixed effects for Pakistan while assuming that other parameters are constant across countries. Given the heterogeneity of the countries' experiences and economic structures, it is doubtful whether complete impacts on all the major economic variables are uncovered for individual countries. This paper examines the effects of military spending on economic growth and other major economic variables for Pakistan. The country provides an interesting example of a low-income country, which has devoted substantial resources to defence over the past 50 years. Generally this has ranged between 6 to 7 percent of GDP putting Pakistan in the top 20 countries ranked in terms of military expenditures as a proportion of GDP by the Stockholm International Peace Research Institute (SIPRI) in $1997 .^{3}$

We test empirically several models that are prevalent in the literature. The data set we use has been constructed for the specific purpose and covers the period

${ }^{3}$ Israel tops the list with 28 percent. Some countries that spend roughly similar percentages are Taiwan (7.1 percent), Chad (6.1 percent), Malaysia (6.7 percent), Iran (6.1 percent), and Myanmar (6.1 percent). India comes in at number 63 with 3.1 percent of its GDP devoted to military expenditures. 
1972 to 1995. Information on most of the variables employed in the study was taken from the International Financial Statistics (IMF) and World Tables (World Bank). We had a choice to make about defence expenditures since there are three sources. These sources are the Government of Pakistan, the U.S. Arms Control and Disarmament Agency (ASACDA), and SIPRI. Nearly all researchers use defence estimates provided by SIPRI or ASACDA since these are considered to be more reliable as the agencies supposedly have no axe to grind. ${ }^{4}$ We use the estimates of Pakistan defence expenditures provided by ASACDA in the paper.

The next three sections are devoted to model formulations and their respective statistical estimations. Most studies assume that defence is determined exogenously and estimate its effects on other economic variables, primarily growth in GDP. Section 2 formally conducts a test for causality in the Granger sense between the defence burden and GDP growth to check whether this is true. Section 3 moves on to posit and estimate several single equation models, that have been influential in the literature, to assess the impact of defence expenditures on GDP growth and other important economic variables. Section 4 formulates and estimates a 3-equation model explaining GDP growth, savings rate, and the defence burden. A brief summary and conclusion section ends this paper.

\section{CAUSALITY: GROWTH TO DEFENCE OR VICE VERSA OR BOTH}

As mentioned above many of the empirical studies on defence and growth have failed to tackle the issue of causality and have gone along with Benoit's (1978) original assumption that causality goes from defence burden to growth. Studies by Joerding (1986) and LaCivita and Fredericksen (1991) have challenged this assumption by employing Granger causality methods. Joerding used a pooled sample containing 15 observations from each of 57 countries. His tests showed that defence expenditures are not exogenous. LaCivita and Fredericksen used 20 to 28 observations for each of 21 countries and their tests showed that there was a bidirectional causality between defence and growth.

In this section we report our findings on Pakistan based on Granger causality tests. The methodology is straightforward and now is standard in most econometric textbooks. We use Hsiao's method that combines Granger causality and Akaike's Final Prediction Error (FPE). This procedure allows for the determination of the optimal lag for each variable and the causal relationship. The first step in Hsiao's procedure is to perform a series of autoregressive regressions on the dependent variable. In the first regression, the dependent variable (GDP growth) is lagged once. In each succeeding regression, one more lag on the dependent variable is added. That is, we estimate $n$ models of the form

${ }^{4}$ See Happe and Wakeman-Lin (1994) for a discussion and evaluation of these and other sources of data on military expenditures. 


$$
G_{t}=\alpha+\sum \beta_{t-i} G_{t-i}+\varepsilon_{t} \text {; where, } i=1, \ldots, n \quad \ldots \quad \ldots
$$

The choice of maximum lag lengths, $n$, is arbitrary but they should be sufficiently large and consistent with the sample size. Our sample runs from 1972 to 1995. We set the maximum lag length to $4 .^{5}$ For each regression FPE was computed as follows:

$$
\operatorname{FPE}(n)=[(T+n+1) / T-n-1)] \operatorname{ESS}(n) / T \quad \ldots \quad \ldots \quad \ldots
$$

Where $T$ is the sample size, and $\operatorname{FPE}(n)$ and $\operatorname{ESS}(n)$ are the final prediction error and the sum of squared residuals, respectively. The optimal lag length $n^{*}$ is the one that gives the lowest FPE. This came out to be one. Once $n^{*}$ was determined, models were estimated with the lags on the other variable added sequentially in the same manner used to determine $n^{*}$. We estimated $m$ (4) models of the form:

$$
G_{t}=\alpha+\Sigma^{n^{*}} \beta_{t-i} G_{t-i}+\Sigma^{m} \gamma_{t-i} D_{t-i}+\varepsilon_{t} \quad \ldots \quad \ldots
$$

Again FPE was computed for each regression equation as:

$$
\operatorname{FPE}\left(n^{*}, m\right)=\left[\left(T+n^{*}+m+1\right) /\left(T-n^{*}-m-1\right)\right] E S S\left(n^{*}, m\right) / T \quad \ldots
$$

The optimal lag length for $D, m^{*}$, is the lag length which has the minimum FPE. This test is equivalent to using a series of $F$ tests with variable levels of significance. Again this turned out to be one lag. To test for causality, the FPE with $D$ omitted from the model, FPE( $\left.n^{*}\right)$ was compared to the FPE with $D$ included in the model, $\left(F P E n^{*}, m^{*}\right)$. They were as follows:

$$
\begin{aligned}
& \text { FPEn* }=2.94 \\
& \text { FPEn }^{*}, m^{*}=2.80
\end{aligned}
$$

As the FPE with defence present is less than without defence we conclude that defence spending Granger-causes economic growth. The steps outlined above were repeated with defence as the dependent variable. The optimal lag lengths were 1 and 2 respectively. The FPEs were:

$$
\begin{aligned}
& \operatorname{FPE}(1)=0.24 \\
& \operatorname{FPE}(1,2)=0.20
\end{aligned}
$$

Since the FPE with GDP growth present in the model is less than FPE without GDP growth included we conclude that GDP growth Granger-causes defence. Therefore there was bi-directional causality between the defence burden and GDP growth during the 1972-95 period.

${ }^{5}$ This is more of a problem in studies employing quarterly, monthly, or higher frequency data. Our study uses annual data, and therefore 4 years is a fairly long time for a variable to have had an impact. 


\section{SINGLE EQUATION MODELS FOR ANALYSING THE EFFECTS OF MILITARY SPENDING ON GROWTH}

As the previous section has shown, there appears to be bi-directional causality running between the defence burden and GDP growth. Therefore single equation models that assume defence to be exogenous may give biased results. Before we go on to a model that allows for both defence and GDP growth to be endogenous, in this section we estimate four single equation models that have been widely used. Besides providing information about the nature of the impacts of defence expenditures on economic growth, this procedure will allow us to determine the appropriate form of the growth equation to be used in a simultaneous framework.

\section{Model 1}

The first model is a military twist on the basic Keynesian model introduced by Benoit (1978) and Faini et al. (1984). We begin with the national accounts identities.

$$
\begin{array}{rrrrrr}
Y=C P+G D+G N D+I+X-M & \ldots & \ldots & \ldots & \ldots \\
S=Y-C P-G N D & \ldots & \ldots & \ldots & \ldots & \ldots
\end{array}
$$

Where $Y$ is income, $C P$ is private consumption, $G D$ is defence expenditures, $G N D$ is non defence consumption expenditures of the government, $I$ is total private and public investment, $X$ is exports, $M$ is imports, and $S$ is savings. The savings and import functions have the simple forms:

$$
\begin{aligned}
& \begin{array}{llllllll}
S=s Y & \ldots & \ldots & \ldots & \ldots & \ldots & \ldots
\end{array}
\end{aligned}
$$

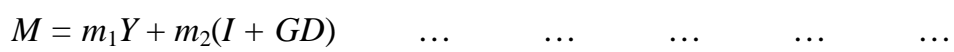

We assume that there is a level of full capacity output, $Y^{*}$, which can be related to the existing capital stock. We therefore define a relative utilisation rate, $u$, as

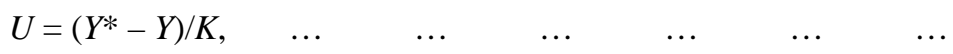

where $K$ is capital stock. We assume that investment responds to the level of capacity utilisation. In Pakistan it is also restrained by absorptive capacity-the ability of the economy to muster skilled workers, management, key pieces of equipment, and other inputs necessary to carry through investment projects. The absorptive capacity limit is specified as:

$$
V=V[(I+G D) / K, Y / K,(E-M) / K, G D / Y, P o p], \quad \ldots \quad \ldots
$$

where Pop represents total population. A larger value of $V$ means that capital formation is more difficult. Higher levels of investment demand, defence spending, or output (relative to capital stock) will put pressure on available supplies of capital, 
skilled labour, and foreign exchange. More available foreign exchange $(E-M)$ will have the opposite effect. The term $G D / Y$ (defence ratio) allows for productive-raising effects of military spending. A reduced form for the real growth rate of GDP, $g$, can be inferred from the equations above. ${ }^{6}$

$$
g=a_{0}+a_{1} x+a_{2} n+a_{3} \Delta(G D / Y)+a_{4} \Delta F+a_{5} k+\varepsilon \quad \ldots \quad \ldots
$$

The explanatory variables are the growth rates of exports, capital stock, and population ( $x, k$, and $n$ respectively), the change in foreign capital inflows $(\Delta F)$, and the change in defence spending share of GDP.

The OLS parameter estimates (corrected for serial correlation) of this equation are as follows:

$$
g=14.49+0.18 x-3.88 n-2.0 \Delta(G D / Y)+0.24 \Delta(F / Y)+0.63 k
$$

Adj. $R^{2}=0.45, F=4.13, D . W .=2.20, \rho=-0.43$

The number in parentheses below the parameter estimates are the $t$ values. Also reported are the adjusted coefficient of multiple determination $\left(R^{2}\right)$, the $F$ value, the Durbin-Watson statistic, and the autocorrelation coefficient. The critical $t$ and $F$ values are 1.711 and 2.55 respectively. ${ }^{7}$ These jointly indicate that the equation is statistically significant and explains 45 percent of the variation in the growth of GDP. Growth in the capital stock has the expected sign. An increase in the defence burden has a negative impact on the growth rate. ${ }^{8}$ However, the coefficient is not statistically significant at a 10 percent level of significance for a two-tail test. For a one-tail test at the 10 percent level of significance, it is statistically significant. Export growth influences economic growth positively.

\section{Model 2}

The second model widely used in the literature is based on an explicit Harrod Domar capital-centred growth equation. In general form it is as follows:

$$
G=f(I O C R, I / Y) \quad \ldots \quad \ldots \quad \ldots \quad \ldots \quad \ldots \quad \ldots
$$

Where IOCR is the incremental output capital ratio and the symbols have been defined before, i.e., $g$ is the growth rate of output and $I / Y$ is the ratio of total investment to GDP. The standard argument against defence expenditures is that, for a given surplus of production over consumption, it diverts funds from investment and

\footnotetext{
${ }^{6}$ See Faini et al. (1984) and Stewart (1991) for details.

${ }^{7}$ This is assuming a two-tail $t$ test at the 90 percent confidence level. For the $F$ test we assume a 95 percent confidence level in this paper.

${ }^{8}$ The term 'defence burden' is interesting and it is widely used in the literature to represent the share of military expenditures in GDP. In a way, the term presupposes the issue.
} 
thus hinders growth. For a closed economy, a higher defence expenditure to GDP ratio $(G D / Y)$ means a lower investment ratio $(I / Y)$. This can be represented as:

$$
I / Y=f(G D / Y), \quad \ldots \quad \ldots \quad \ldots \quad \ldots \quad \ldots \quad \ldots
$$

where $I / Y$ and $G D / Y$ are expected to be negatively related. Foreign capital inflows may enable a country to increase its defence and investment expenditures at the same time. In order to isolate the effect of defence spending on economic growth, we incorporate foreign capital inflows in the trade-off model and rewrite Equation (14) as:

$$
I / Y=f(G D / Y, F / Y), \quad \ldots \quad \ldots \quad \ldots \quad \ldots \quad \ldots
$$

where $F / Y$ is the foreign capital inflow to GDP ratio. For a given $G D / Y, F / Y$ and $I / Y$ are hypothesised to be positively related. ${ }^{9}$ The substitution of Equation (15) into Equation (13) gives the following estimating equation:

$$
g=b_{0}+b_{1} I O C R+b_{2}(G D / Y)+b_{3}(F / Y)+b_{4}(S / Y)+\varepsilon \quad \ldots \quad \ldots
$$

We include the savings ratio $(S / Y)$ in addition to foreign capital inflows as it brings out more directly the impact that different sources of funds have on investment and defence expenditures. The estimated equation (corrected for serial correlation) is:

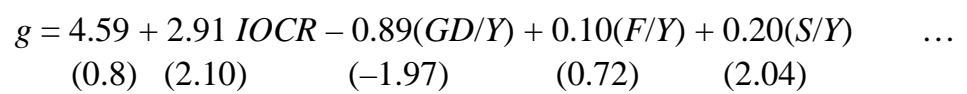

Adj. $R^{2}=0.28, F=2.74, D . W .=2.17, \rho=-0.19$,

where $\rho$ is the autocorrelation coefficient. The equation is statistically significant at the 5 percent level. Both $I O C R$ and $G D / Y$ are statistically significant and although the effect of $(F / Y)$ is positive, it is not statistically significant. In a similar framework, Lim's (1983) findings that defence is not related to growth for 11 Asian countries are not supported by our results. However, our results do support Lim's finding that capital flows do not have much impact on growth. ${ }^{10}$

\section{Model 3}

Following up on the Harrod-Domar model, subsequent substantial growth theory contributions include Solow (1970); Hicks (1965) and Lucas (1988). The contributions made by these and several other economists have provided the theoretical foundations for the typical rendition of the empirical neo-classical growth

${ }^{9}$ Foreign capital flows could be disaggregated into bilateral and multilateral flows. Khilji and Zampelli $(1991,1994)$ have found that U.S. bilateral aid is generally treated as a fungible resource by Pakistan, Israel, Jordan, India, Egypt, Turkey, Thailand, and Philippines. Most of it is channelled to defence and private consumption with negligible impacts on investment.

${ }^{10} \mathrm{Lim}$ does not provide the names of the 11 Asian countries in the paper. 
model found in the growth and development literature today. ${ }^{11}$ In a recent paper Nelson and Singh (1994) modify the Harrod-Domar model to include defence and other important policy variables. They estimate the resulting model based on a cross-section data set for 70 countries. Their model (modified by us for Pakistan) is as follows:

$$
g=c_{0}+c_{1}(D / Y)+c_{2}(G D / Y)+c_{3}(G R / Y)+c_{4}(I / Y)+c_{5} I N F+c_{6} n+\varepsilon,
$$

where $D$ is the government deficit, GR is government revenue, and INF is the inflation rate. Other symbols retain the same meaning as before. Government policies toward spending, taxation and regulation can have important effects on capital formation, labour force growth, and technological progress. The policy variables included are the fiscal deficit $(D)$, and overall government size proxied by government revenues, military expenditures, and public investment. ${ }^{12}$ As the fiscal deficit variable is not adjusted for the effects that inflation might have on the real deficit, inflation rate is also included.

The estimated equation (corrected for serial correlation) is as follows:

$$
\begin{aligned}
& g=22.74-0.20(D / Y)-0.68(G D / Y)-0.10(G R / Y) \\
& \begin{array}{llll}
(1.77) & (-1.60) \quad(-1.82) \quad(-0.36)
\end{array} \\
& +0.46(I / Y)-0.21 I N F+0.08 n \\
& \begin{array}{llllll}
(1.85) & (-2.14) & (0.03) & \ldots & \ldots & \ldots
\end{array}
\end{aligned}
$$

Adj. $R^{2}=0.34, F=2.76, D \cdot W .=2.18, \rho=-0.39$

We find that all government policy variables affect growth negatively although $G R$ and $D$ are not statistically significant. Nelson and Singh (1994) found that the budget deficit ratio and defence ratio were negative for low-income countries in their sample but not statistically significant. The government ratio was found to positively influence growth but again was not statistically significant. Inflation strongly retards growth both in Pakistan (our findings) and in low-income countries as found by Nelson and Singh. Unlike Nelson and Singh's findings of positive and statistically significant effects of population growth, our results do not find that the variable has an independent effect in this augmented model.

\section{Model 4}

The final single equation model that we will use is based on the widely cited 1975 World Bank study by Chenery and Syrquin. They state their dependent

\footnotetext{
${ }^{11}$ The work by Barro (1991) has also been influential in spawning the vast literature that uses cross-country regressions to search for empirical linkages between average growth rates and socioeconomic and public policy indicators. See Levine and Renelt (1992) for a critical review.

${ }^{12}$ We were unable to obtain a separate series for public investment. Therefore, total investment, instead of a disaggregation of it, is used here.
} 
variables in the form of ratios to GDP, and with incorporation of the defence ratio their equation becomes:

$$
\begin{aligned}
Z / Y= & d_{0}+d_{1} \log (Y / P o p)+d_{2}[\log (Y / P o p)]^{2}+d_{3} \log (P o p)+ \\
& d_{4}[\log (P o p)]^{2}+d_{5} F+d_{6}(G D / Y)+\varepsilon, \quad \ldots \quad \ldots
\end{aligned}
$$

where $Z$ represents different important economic variables. By doing this we can trace through other possible effects of defence spending on the Pakistan economy. The estimated parameters giving the effects of the defence ratio variable on important variables in Pakistan are reported in Table 1.

Table 1

Coefficients of the Defence Burden Variable in Equation (20) for the Following Variables in Pakistan

\begin{tabular}{lcc}
\hline Variables & Coefficients & $t$-Ratios \\
\hline Investment/GDP & -0.184 & -0.78 \\
Imports/GDP & 0.333 & 0.43 \\
Agriculture/GDP & 0.718 & 1.02 \\
Industry/GDP & 0.582 & 1.02 \\
Tertiary Sector/GDP & 2.095 & 1.37 \\
Tax Receipts/GDP & -0.514 & -1.28 \\
GDP Growth Rate & -0.640 & -1.66 \\
Growth of Non-defence Output & -1.105 & -1.67 \\
\hline
\end{tabular}

Other than the negative and statistically significant effects on GDP growth and growth of non-defence output, the defence burden has no statistically significant effects on the other important variables in the economy. In a similar study for India for the 1951-1972 period, Faini et al. (1984), found the defence burden to have positive and statistically significant effects on investment share, industry share, tax receipts ratio. It affected negatively, and statistically significantly, agricultural output. While there were negative effects on GDP growth and nondefence output growth, they were not statistically significant. ${ }^{13}$

\section{A THREE-EQUATION MODEL FOR PAKISTAN}

The single equation models for Pakistan reported in the previous section generally give statistically significant coefficients, have the right signs predicted by economic theory, and are based on the structural characteristics of Pakistan as they pertain to military spending and growth. However, neither the results nor the estimation methods reflect the degree of interdependence that exists between these

\footnotetext{
${ }^{13}$ Our study is strictly not comparable to theirs since they did it for a much earlier period for India. Moreover, India’s defence ratio is about half of Pakistan's.
} 
variables. Therefore, conclusions derived from such models may be misleading. In this section we specify a three-equation model and report the results of estimating the model as a system. Equations are developed for the savings-income ratio, and the military burden.

As the previous section has focussed on estimating several equations for GDP growth we have to make a choice of which one to include in the simultaneous model. Equation (16), in Model 2, is satisfactory for the purpose. It is derived systematically within an explicit conceptual framework and has all the important variables whose effects we are interested in studying. The national savings ratio would clearly depend upon economic growth as suggested by economic theory. If it is taken to be an indicator of resources available to the economy, then the effect of inflation on resource creation would be important to understand. Whether foreign capital inflows retard or encourage national savings is another issue that can be empirically investigated. It is probably true that the most important channel through which defence can influence growth is the creation and mobilisation of extra savings for the economy. Therefore the role of the defence burden in affecting the average propensity to save is important to ascertain. Based on these considerations we posit the following general form for the savings ratio:

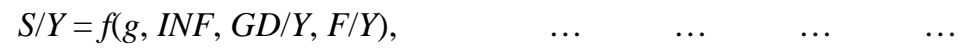

where growth is expected to influence the savings ratio positively. The signs on the other variables cannot be indicated a priori. Several forms of the equation were experimented with. This including imposing various lag structures on the explanatory variables, excluding each variable to see how its absence affected the values and statistical significance of the remaining variables. ${ }^{14}$ The estimated equation that was most satisfactory, based on economic theory and statistical tests, is as follows:

$$
\begin{array}{rllll}
S / Y= & -9.51+0.26 g-0.67 I N F+0.13(F / Y)+5.07(G D / Y) & \ldots & \ldots \\
& (-0.80)(1.61) & (-3.90) & (0.45) & (3.68)
\end{array}
$$

Adj. $R^{2}=0.72, F=14.92, D . W .=1.93$.

The positive influence of the defence burden on the national savings rate is remarkable. It may be because of increased savings resulting from the sale of defence bonds or a moral dedication toward greater savings, and austerity in times of national crises. Pakistan has had many national crises. On the other hand inflation has a negative and statistically significant effect on the savings ratio.

Extensive experimentation was done to find the determinants of military burden $(G D / Y)$. In all specifications GDP growth could not explain the defence

${ }^{14}$ These results and the results of experimentation with alternative forms of the defence ratio equation are available from Nasir Khilji. 
burden. What did turn out to be crucial in explaining defence was government consumption spending as a proportion of GDP. Foreign capital inflows were not statistically significant in all specifications. Defence is also a major public good, and conventional public finance theory suggests that it be dependent on total population. The effect of security related and strategic considerations were investigated by including Indian defence expenditures (taken from USACDA) as a ratio of India's GDP. An alternative variable used was the ratio of Indian defence expenditures and Pakistani defence expenditures. In all specifications, including different lag structures, both variables came in as negative and statistically significant. While this result goes against the conventional view in Pakistan, it can be explained by the fact that Indian defence expenditures by themselves do not cause Pakistan security concerns to be heightened. It is what those expenditures are devoted to that probably matters as much, if not more.

In an interesting theoretical and empirical paper on the Indo-Pakistani arms competition, Oren (1994) reaches the same conclusion. Oren's empirical findings are consistent with his findings for the superpowers' case: India and Pakistan are found to have matched high levels of armaments with low levels and vice-versa. Our results and Oren's findings contradict conventional wisdom on power balancing. Oren's theory explains this anomalous phenomenon. States use strength not just as an indicator of capability but also of intentions. Given the same amount of hostile behaviour, weak states appear more aggressive than strong ones.

The most satisfactory estimated equation for the defence burden is as follows:

$$
\begin{aligned}
& (G D / Y)=3.68+0.21(G C / Y)-0.85\left(G D_{I N} / Y_{I N}\right)+0.89 n \quad \ldots \quad \ldots \\
& \text { (2.26) (3.63) } \quad(-1.73)
\end{aligned}
$$

$$
\text { Adj. } R^{2}=0.55, F=7.84, D . W .=1.95
$$

Where $G C$ is government consumption expenditures and $G D_{I N}$ and $Y_{I N}$ are Indian defence expenditures and GDP respectively.

Equations (17), (22), and (23) were re-estimated as a system by the full information maximum likelihood method (FIML) using TSP 4.2B. This is to account for simultaneity and high covariance between the equations. The empirical results are as follows:

$$
\begin{aligned}
& g=6.38+2.56 \operatorname{IOCR}-1.11(G D / Y)+0.08(F / Y)+0.20(S / Y) \quad \ldots \\
& \text { (1.24) (2.04) (-1.36) (0.60) (2.21) } \\
& R^{2}=0.30, D . W . \text { Statistic }=2.17 \\
& S / Y=9.95+0.14 \mathrm{~g}-0.30 I N F-0.32(F / Y)+1.82(G D / Y) \quad \ldots \\
& \begin{array}{llll}
(1.00) & (1.52) \quad(-1.91) \quad(-1.21) \quad(1.34)
\end{array} \\
& R^{2}=0.50, D . W . \text { Statistic }=1.67
\end{aligned}
$$




$$
\begin{aligned}
& (G D / Y)=3.91+0.19(G C / Y)-0.64\left(G D_{I N} / Y_{I N}\right)+0.69 n \quad \ldots \quad \ldots \\
& \text { (2.30) (2.84) (-1.24) (1.31) } \\
& R^{2}=0.58, D . W . \text { Statistic }=1.96
\end{aligned}
$$

On comparing Equations (17) and (24) which explain GDP growth we find that by performing a systems estimation the explanatory power of the equation goes slightly up. Generally the parameter estimates and their statistical significance has not changed much except for the defence burden variable which becomes statistically insignificant. However, the point estimate of its effect on growth has gone up (become more negative). Comparison of the single equation estimates with system estimates for the savings ratio [Equations (22) and (25) respectively] reveals that all parameters except for inflation become statistically insignificant. The point estimate for the defence burden variable goes down tremendously. Although the defence burden has a positive effect on the savings ratio, it is statistically insignificant.

The point estimates, except for the constant term, in the defence burden equation decrease when we estimate it as part of a system [Equation (26)]. Only the government budget variable comes in as statistically significant. While the Indian defence burden stays inversely related to the Pakistan defence burden, it is no longer statistically significant.

\section{SUMMARY AND CONCLUSIONS}

This paper represents a preliminary attempt at exploring the impacts of defence expenditures on economic growth and other major economic variables in the Pakistan economy. We use a time series annual data set especially constructed for this purpose. The data set covers the period 1972-1995. The results of Grangercausality test show that there is bi-directional feedback between the defence burden and GDP growth.

We test four different single equation models that are widely used in the defence literature. In these frameworks we generally find the defence burden to be negatively related to GDP growth, growth of non-defence output, investment ratio, and tax revenues as a ratio of GDP. The agriculture, industry, and tertiary sector outputs, as ratios of GDP, are affected positively by the defence ratio. However the statistical significance of nearly all these relationships is questionable.

Finally, we specify a three-equation model which explains GDP growth, average propensity to save, and the defence ratio. In single equation estimations of the savings ratio and the defence burden, we uncover some interesting relationships. The savings ratio is affected positively by the defence ratio, and negatively by the inflation rate. The Pakistani defence burden is impacted negatively by the Indian defence burden and positively by the government budget. When all three equations are estimated as a system to account for feedback and covariance between these equations, these effects are diminished and go down in statistical significance. 
In light of our investigation for Pakistan it appears that the interconnection between defence and growth is not simply a gun and butter problem with a necessarily inverse trade-off between the two. Future research efforts should be geared to understanding more clearly the determinants of defence expenditures with explicit recognition of the strategic environment that Pakistan finds itself. This would include endogenising India's strategic considerations. Also the effect of the military complex on political stability/instability in the country and the latter's effect on economic growth would have to be uncovered. All this implies the analysis of more complex interrelationship. Hopefully, such an analysis will also be more intellectually satisfying.

\section{REFERENCES}

Alesina, A., S. Ozler, N. Roubini, and P. Swagel (1991) Political Instability and Economic Growth. (NBER Working Paper.)

Baffes, John and Anwar Shah (1993) Productivity of Public Spending, Sectoral Allocation Choices, and Economic Growth. Policy Research Development, The World Bank. (WPS 1178.)

Ball, Nicole (1983) Defence and Development: A Critique of Benoit Study. Economic Development and Cultural Change.

Barro, R. J. (1991) Economic Growth in a Cross Section of Countries. Quarterly Journal of Economics 106.

Bayoumi, Tamim, Daniel Hewitt, and Jerald Schiff (1993) Economic Consequences of Lower Military Spending: Some Simulation Results. Fiscal Affairs and Research Department, International Monetary Fund, March. (Working Paper, WP/93/17.)

Bayoumi, Tamim, Daniel Hewitt, and Steven Symansky (1993) The Impact of Worldwide Military Spending Cuts on Developing Countries. Research and Fiscal Affairs Department, International Monetary Fund, November. (Working Paper, WP/93/86.)

Benoit, Emile (1973) Defence and Economic Growth in Developing Countries. Boston: D. C. Heath \& Co.

Benoit, Emile (1978) Growth and Defence in Developing Countries. Economic Development and Cultural Change.

Blomberg, S. Brock (1996) Growth, Political Instability, and the Defence Burden. Economica 63.

Boretsky, M. (1975) Trends in U.S. Technology: A Political Economist's View. American Scientist 3: January-February.

Chan, S. (1985) The Impact of Defence Spending on Economic Performance: A Survey of Evidence and Problems. Orbis 29.

Faini, Ricardo, Patricia Annez, and Lance Taylor (1984) Defence Spending, Economic Structure, and Growth: Evidence Among Countries and Over Time. Economic Development and Cultural Change. 
Grossman, H. (1991) A General Equilibrium Theory of Insurrections. American Economic Review 81.

Happe, N., and J. Wakeman-Linn (1994) Military Expenditures and Arms Trade: Alternative Data Sources. Policy Development and Review Department, International Monetary Fund, June. (Working Paper, WP/94/69.)

Hess, G., and A. Orphanides (1991) War Politics: An Economic Rational Voter Framework. (Federal Reserve Board Working Paper.)

Hicks, J. R. (1965) Capital and Growth. New York: Oxford University Press.

Joerding, Wayne (1986) Economic Growth and Defence Spending: Granger Causality. Journal of Development Economics 21.

Khilji, Nasir M. and Ernest M. Zampelli (1991) The Fungibility of US Assistance to Developing Countries and the Impact on Recipient Expenditures: A Case Study of Pakistan. World Development 19:8.

Khilji, Nasir M., and Ernest M. Zampelli (1994) The Fungibility of U.S. Military and Non-Military Assistance and the Impacts on Expenditures of Major Aid Recipients. Journal of Development Economics April.

LaCivita, Charles J., and Peter C. Frederiksen (1991) Defence Spending and Economic Growth: An Alternative Approach to the Causality Issue. Journal of Development Economics, 35.

Levine, R., and D. Renelt (1992) A Sensitivity Analysis of Cross-country Growth Regressions. American Economic Review 82.

Lim, David (1983) Another Look at Growth and Defence in Less Developed Countries. Economic Development and Cultural Change.

Londregan, J., and K. Poole (1990) Poverty, the Coup Trap, and the Seizure of Executive Power. World Politics 42.

Lucas, R. W. (1988) On the Mechanics of Economic Development. Journal of Monetary Economics 22:1 July.

Nelson, M. A., and R. D. Singh (1994) The Deficit-Growth Connection: Some Recent Evidence from Developing Countries. Economic Development and Cultural Change.

Oren, Ido (1994) The Indo-Pakistani Arms Competition: A Deductive and Statistical Analysis. The Journal of Conflict Resolution June.

Sivard, R. L. (1977) World Military and Social Expenditure. Leesburg, VA: WMSE Publications.

Smith, R. P. (1977) Military Expenditure and Capitalism. Cambridge Journal of Economics 1: March.

Smith, R. P. (1989) Models of Military Expenditure. Journal of Applied Econometrics 4.

Solow, R. W. (1970) Growth Theory: An Exposition. New York: Oxford University Press.

Stewart, Douglas B. (1991) Economic Growth and the Defence Burden in Africa and Latin America: Simulations from a Dynamic Model. Economic Development and Cultural Change. 